\title{
DEVELOPMENT OF MATZO MADE OF WHOLEMEAL RYE FLOUR AND ITS IMPLEMENTATION IN THE INDUSTRY
}

\author{
Zita Boglárka Zakupszki, Antal Véha, Balázs Szabó P. \\ University of Szeged, Faculty of Engineering, Moszkvai krt. 5-7., 6725, Szeged, Hungary, \\ e-mail: z.zita@mk.u-szeged.hu
}

\begin{abstract}
In the baking industry, continuous development of products is required because consumers with different nutritional needs are pushing for new requirements for food. Along with the low caloric content, there is growing attention to the functional effects of foods.

The aim of our work is the development of a matzo made of wholemeal rye flour, which helps in healthy nutrition for the customer's and more economical from production's point of view. The main aim of the product development in our project is to increase the nutrient content by the raise of mineral and fibre content.

In the first part of our work we performed basic measurements with flours used during product development. We measured the quantity and quality of gluten protein with Glutomatic-Gluten Index System, the activity of amylase enzymes with Falling Number 1400 and we did complex dough monitoring with METEFÉM Valorigraphe FQA 205. In the second part of our project we compare the basic matzo with matzos made of 3 different recipes. Based on results of examinations it can be ascertain that the Sample 2 shows more advantageous values of the fibre content's and the prime cost's point of view.
\end{abstract}

Key words: trend, development, nutrition, matzo

\section{INTRODUCTION}

Bakery products are one of the most important food sources of the population [1]. Their protein, carbohydrate and vitamin content make their consumption an energy supplement in everyday life. The consumed foods help to maintain health, provide good physical and mental strength.

In the baking industry, continuous development of products is required because consumers with different nutritional needs are pushing for new requirements for food. Along with the low caloric content, there is growing attention to the functional effects of foods. Enriched bakery products are, overall, functional foods that have proven beneficial health effects along with their basic nutritional effects. It is important during nutrition that the process does not affect the basic organoleptic properties of the product [2].

In our work, we focused to increase the fibre content in a special bakery product which development is one of the main trends in the development of food in the baking industry [3]. Food fibers are complex, non digestible carbohydrates. The fibers are useful in preventing a number of diseases and abnormal conditions. Most importantly, they help reduce blood cholesterol levels, stabilize blood glucose, and also play a role in preventing colon cancer, obesity and constipation [4]. As a result, it is essential for the body to receive fiber in order to facilitate its normal operation.

We chosed the matzo for our work because, thank for its simple recipe and technology, it's very suitable for product development for consumers with different nutritional needs. Matzo is crisp and vesicular, unleavened bread made with water and flour, which is gastronomic and religiously important in Jewish culture. They can be consumed not only in bread form (Fig. 4), but are often used as raw materials for foods. 
On the basis of the traditional recipe, matzo is characterized by a kind of neutral flavor, which is due to the fact that only flour and water are used during the preparation. The product does not contain added salt, sugar, spices or other substances. Thanks to the industrial revolution, when the mass production of matzo began, it was enriched with various materials to expand the customer circle. The reception of flavored products was different because of different world perceptions, but has now been accepted in several places. Bread consumption is now widespread and can be consumed by young children as it is easily digestible thanks to its simple composition. It is an ideal supplement to diets as opposed to traditional white bread, it does not contain yeast, fat, so its energy content is low.

\section{MATERIALS AND METHODS}

In the first part of our work we performed basic measurements with flours used during product development. We measured the quantity and quality of gluten protein with Glutomatic-Gluten Index System (Fig. 1), the activity of amylase enzymes with Falling Number 1400 (Fig. 2) and we did complex dough monitoring with METEFÉM Valorigraphe FQA 205 (Fig. 3) of BL80, BL160, RL90 and RLTK flours.

The gluten test was performed on the MSZ EN ISO 21415-1, MSZ EN ISO 21415-2 and MSZ EN ISO 21415-4 standards. During the study we determined the Gluten-index and the water absorption capacity of gluten protein from flours. By defining the Gluten-index, we can qualify the gluten proteins of the examined flours, thus determining the structure and physical properties of the dough and the degree of its gas retention, and the baking usability. The gluten test was performed only with wheat flours.

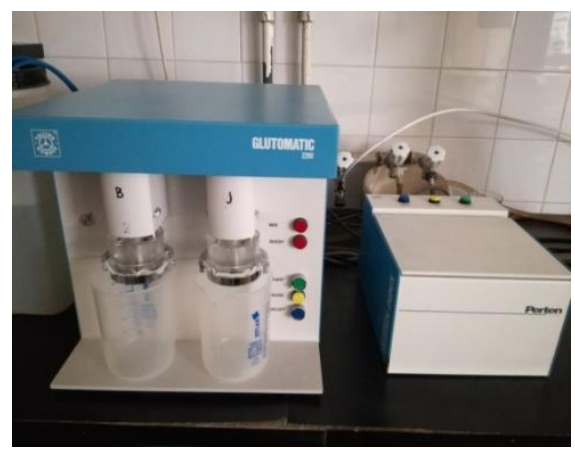

Figure 1. Glutomatic-Gluten Index System

The activity of amylase enzymes was tested according to the MSZ 6369-9:1977standard. During the test, the enzyme content of the flours and their activity can be characterized, and the baking usability of flours. 


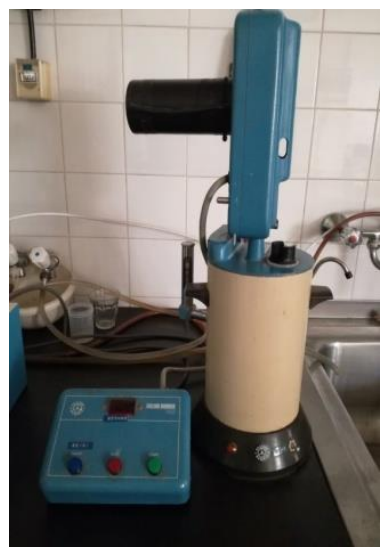

Figure 2. Falling Number 1400

The complex dough monitoring was carried out according to MSZ 6369-6:2013 standard. During the measurement, the water absorption capacity and physical properties of the examined flour can be quantified.

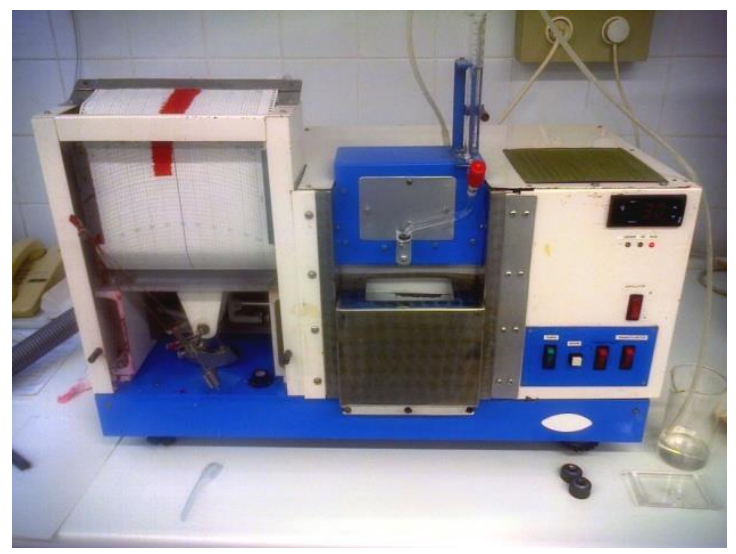

Figure 3. METEFÉM Valorigraphe FQA 205

In the second part of our project we compare the basic matzo with matzos made of 3 different recipes (Fig. 4). We named the basic matzo for Sample 1, and the 3 others for Sample 2, Sample 3 and Sample 4. 


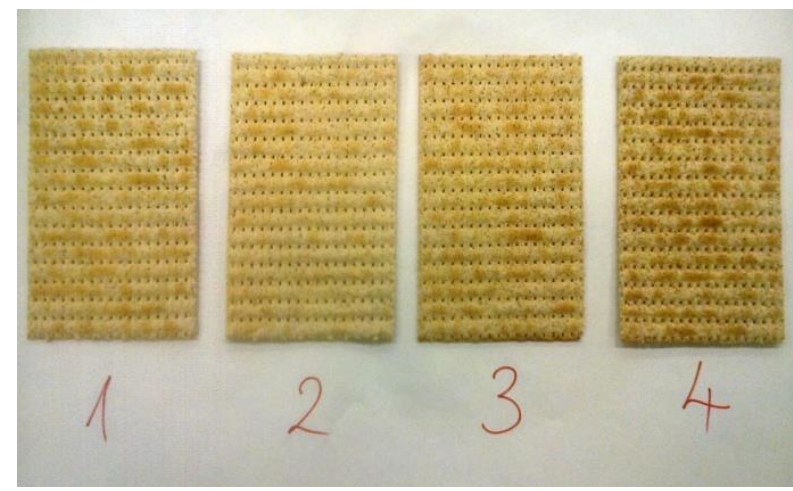

Figure 4. Comparison of basic matzo (No. 1) and matzos made of 3 different recipes (No. 2, 3, 4)

There was no change in the production method, for example baking temperature, only the composition was changed. During development, we must take into account that the new products meet the quality requirements of the basic matzo. The basic matzo contains only BL80 and RLTK flour, but the other 3 types of matzo contain different percentages of BL80, BL160, RL90 and RLTK flour. The composition of the new patterns is shown in Tab. 1. In view of the basic requirement, it is true for each product that its rye flour content is at least $40 \%$. The amount of water used was determined by the quality of the dough made from different flours, and its suitability for further machining.

Table 1. Composition of the samples per $100 \mathrm{~g}$ finished product

\begin{tabular}{|c|c|c|c|c|}
\hline \multirow{2}{*}{$\begin{array}{c}\text { Sample } \\
\text { code }\end{array}$} & \multicolumn{4}{|c|}{ Materials [g/100 g of finished product] } \\
\cline { 2 - 5 } & BL80 & BL160 & RL90 & RLTK \\
\hline Sample 2 & - & 60 & - & 40 \\
\hline Sample 3 & 40 & - & 20 & 40 \\
\hline Sample 4 & 40 & - & - & 60 \\
\hline
\end{tabular}

We measured the ash content according to MSZ 20501-1:2007 standard, the acid content according to MSZ 6369/11-87 standard, and fibre content with 2010 Fibertec System (Fig. 5) according to MSZ 6369/12-79 standard of matzo samples. We investigated the functional properties of the product under these tests. Then we made an organoleptic measurement and an economic calculation. 


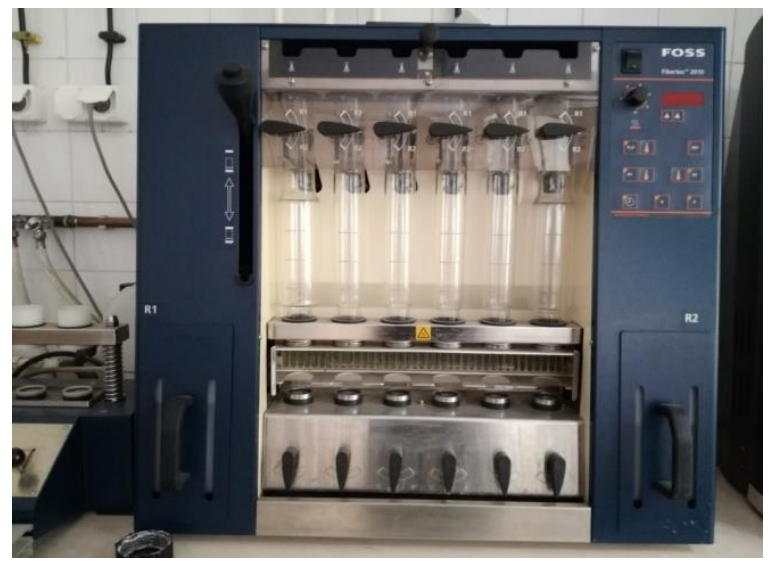

Figure 5. 2010 Fibertec System

\section{RESULTS AND DISCUSSION}

In the course of the studies we have found that BL80 and BL160 contain large amount of strong gluten proteins and each flour is low in enzyme content. In the baking industry flours with low enzyme content have negative impacts on the properties of the product but this feature doesn't matter to the matzo. In the dough monitoring it was found that each flour is suitable for matzo making, but RL90 is only slightly recommended because the large amount of water it absorbs reduces the efficiency of production.

During determining the ash content, we also determined the moisture content of the matzo samples. It can be concluded that none of the samples exceeds the moisture content of the Sample 1. Taking together the ash content and the moisture content, the most prominent data were found in Sample 4, but in measuring the acid content of matzos the results of Sample 4 are the worst. (Tab. 2) The reason for this is probably that Sample 4 contained large amounts of RLTK flour. The aim of our work is to find new recipes that result in higher fiber content. After determining the fiber content, it can be concluded that Sample 4 showed the best results during this study (Tab. 2). In addition, the fiber content test showed that the lowest value was shown in Sample 3. From this we can conclude that if some of the BL80 is replaced by RL90, the fiber content of the product decreases. 
Table 2 Test results of the matzos

\begin{tabular}{|c|c|c|c|c|}
\hline \multirow{2}{*}{$\begin{array}{c}\text { Sample } \\
\text { Code }\end{array}$} & $\begin{array}{c}\text { Moisture } \\
\text { content } \\
\text { [\%] }\end{array}$ & $\begin{array}{c}\text { Ash } \\
\text { content } \\
\text { [\%] }\end{array}$ & $\begin{array}{c}\text { Acid } \\
\text { content } \\
\text { [ml/g] }\end{array}$ & $\begin{array}{c}\text { Fibre } \\
\text { content } \\
\text { [\%] }\end{array}$ \\
\hline \multirow{2}{*}{ Sample 1 } & 5,23 & 0,87 & 3,45 & 1,43 \\
\cline { 2 - 5 } & 5,33 & 0,86 & 3,55 & 1,41 \\
\hline \multirow{2}{*}{ Sample 2 } & 5,02 & 1,00 & 3,70 & 1,45 \\
\cline { 2 - 5 } & 5,05 & 0,99 & 3,80 & 1,43 \\
\hline \multirow{2}{*}{ Sample 3 } & 5,37 & 0,99 & 3,80 & 1,39 \\
\cline { 2 - 5 } & 5,37 & 0,97 & 3,90 & 1,42 \\
\hline \multirow{2}{*}{ Sample 4 } & 4,70 & 1,06 & 4,05 & 1,73 \\
\cline { 2 - 5 } & 4,69 & 1,05 & 4,00 & 1,68 \\
\hline
\end{tabular}

The organoleptic measurement included a critical group of 19 participants. During the organoleptic measurement, judges were asked to evaluate Samples 2, 3 and 4 from 1 to 3. Figure 6 shows that the most preferred sample for the consumer was the Sample 2. The least favoured product was the Sample 4.

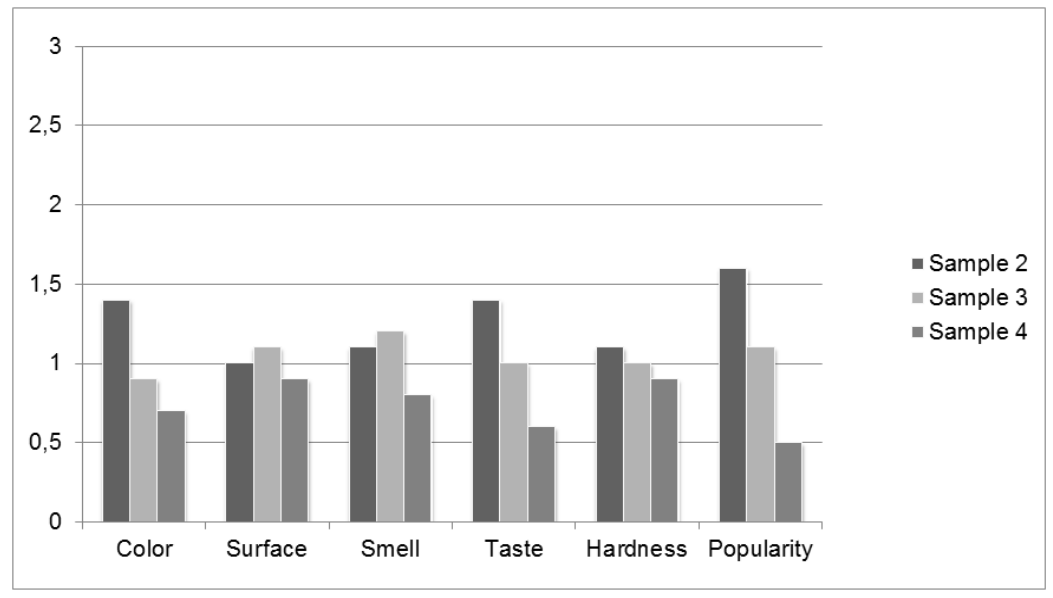

Figure 6 Compare the ranking of the samples made of new recipes

In the economic calculation, the direct material cost is determined by the quantity and knowledge of the flours used. The calculation shall take account of the loss of mass during baking and cooling. In the economic calculation it can be stated that Sample 2 requires the lowest production cost. 


\section{CONCLUSIONS}

Based on our investigations we can conclude that the product development was successful, with the production of Sample 2 higher fiber content, popular and cheaper matzo can be produced. The sample complied with all requirements and fulfilled the goal of product development. The ash content and the fiber content of Sample 2 is the highest after Sample 4's, therefore our decision was greatly influenced by the opinion of consumers in organoleptic measurement. According to the organoleptic measurement, the 60:40 ratio of BL160 and RLTK in the product is the most favourable, which is manifested mainly in colour and taste scores, and the indicator of product popularity is higher than the others (min. $40 \%$ ).

\section{REFERENCES}

[1] http://datatopics.worldbank.org/consumption/product/Bread

[2] Dr. Markovics Erzsébet, Élelmiszeripari adalékanyagok és tápértéknövelő anyagok, Juhász Gyula Felsőoktatási Kiadó, Szeged, 2007, pp. 110-124.

[3] Szabó P. Balázs, A hazai sütőipar helyzete napjainkban, Jelenkori társadalmi és gazdasági folyamatok, XII. issue, No. 1-2., 2017

[4] Dr, habil Fenyvessy József, Jankóné dr.Forgács Judit, Általános élelmiszeripari technológia, Szegedi Tudományegyetem, Szeged, 2000, pp. 25. 